\title{
СРАСЛИЦЕ И ПОЛУСЛОЖЕНИЧКЕ КОНСТРУКЦИЈЕ У РОМАНУ СПЛЕТКАРЕЊЕ СА СОПСТВЕНОМ ДУШОМ МАРИЈЕ ЈОВАНОВИЋ ${ }^{* *}$
}

\begin{abstract}
У раду се разматрају сраслице и полусложеничке конструкције употребљене у роману Сплеткарење са сопственом душом Марије Јовановић. Извршена је типологија посматраних конструкција према критеријуму сраслости њихових конституената, и то на основу структуре регистрованих модела и учесталости употребе у контексту романа. Истовремено, ове јединице се посматрају и са деривационог аспекта као иновативне могућности у лексичком систему српског језика. Резултати анализе показују да су њихова продуктивност и примена најчешће на нивоу језичког експеримента и да су оне углавном условљене контекстом - темом и садржајем самог уметничког текста. Мимо садржаја овог књижевног дела, анализиране сраслице, па и полусложеничке конструкције, немају употребну вредност. Овај податак је важан показатељ да оне поседују известан семантичко-деривациони потенцијал, али и да је творба сраслица непродуктивна у српском језику.
\end{abstract}

Кључне речи: сраслице, полусложеничке конструкције, српски језик.

\section{1. Корпус - роман Сплеткарење са сопственом душом Марије Јовановић}

За корпус је одабран роман Сплеткарење са сопственом душом Марије Јовановић, савремене српске књижевнице. Она се укупним стваралаштвом уклапа у линију женског српског писма, и то на основу теме и специфичне поетике коју развија у својим делима. Значајан допринос разумевању и интерпретацији нове концептуализације стваралаштва појединих српских књижевница дала је Магдалена Кох, пољски слависта. Она сматра да је ме-

*gordanastasni@ff.uns.ac.rs

** Рад је настао у оквиру пројекта Стандардни српски језик: синтаксичка, семантичка и прагматичка истраживања (бр. 178004), који финансира Министарство просвете, науке и технолошког развоја Републике Србије. 
тодолошка тријада - канон, жанр и род важна допуна традиционалном филолошком истраживању (Кох 2012).

На књижевни опус Марије Јовановић могу се односити и речи Владиславе Гордић Петровић (2011: 309), иако се она у раду поменуте ауторке експлицитно не наводи. Женски ауторски рукопис развијао се у неколико праваца крајем прошлог и у првој деценији овог века. „И поред поетичких разлика, српске списатељице имале су исту амбицију: бекство из задатог стања невидљивости уз помоћ стратегија потврђивања женских приповедних модела. Свака је бекство реализовала на другачији, особен начин: експериментом са исповедношћу, тенденцијама алтернативног и апокрифног читања историје, жанровском персифлажом" (Гордић Петровић 2011: 309).

Овај роман тематски прати традиционални канон љубавног романа, али је основна тема уметнички интерпретирана са различитих аспеката. У промишљање о љубави, смислу живота и смрти ауторка у лирско-поетичне садржаје инкорпорира и филозофско, па и религиозно виђење ових проблема. Она на један прилагођен и поприлично симплификован начин уводи у своју приповедачку нит мисли и дела великих филозофа, али и библијске парафразе, поткрепљујући тако своју основну идеју. Роман је стога вишеслојан и надилази основну љубавну причу. Није изостављен ни друштвенополитички и културни утицај на одабир мотива и смештања радње у одговарајући хронотоп. ${ }^{1}$

\section{2. Предмет истраживања}

Овај роман није нам привукао пажњу својом поетиком, жанром или женским писмом, већ језиком и појединим језичким и правописним решењима које ауторка у њему примењује. Сраслице и полусложеничке конструкције одабране су за предмет истраживања углавном из дериватолошких разлога, али будући да се овим конструкцијама у роману постижу одређени стилски ефекти, оне су и специфичност језика дела и указују на креативну и иновативну димензију ауторкиног изражавања. Питање је, међутим, колико су овакве конструкције функционалне на општијем лексичком плану и какав је њихов статус у лексикону српског језика.

\footnotetext{
${ }^{1}$ Главна јунакиња склона интроспекцији и изразитом критицизму загледана је у себе, своју прошлост, живот око себе, своју земљу, породицу, пријатеље... Она никога и ништа не идеализује, а ипак гради као од крпица свој свет прожет емоцијама, младалачким заносом, неоствареним и тужним љубавима, погрешним одлукама, испаштањима, покајањем...
} 


\section{3. Представљање и интерпретација ексцерпиране грађе}

\section{1. Сраслицее}

У дериватологији постоје различита тумачења и различити приступи сраслицама. Полазимо од става М. Стевановића који објашњава настанак сложеница употребом термина срастање (1964: 414), те отуда интерпретатори Стевановићевог виђења овог проблема сматрају да он „не прави никакву разлику између сраслица и осталих сложеница" (Клајн 2002: 28). Међутим, М. Стевановић је у опису сложеница уочио важне проблеме који ће касније бити у основи разматрања будућих дериватолога. Он образлаже да сложенице настају срастањем двеју или више посебних речи у једну. „Одређеније казано: сложенице су речи које су постале срастањем појединих реченичних делова или и целих реченица састављених од најмање две речи", нпр. југоисток (од југ и исток), плавокоса (од плава коса), дангубити (од дан губити), акобогда (од ако бог да) итд. У састав сложеница улазе речи или они делови реченице „што су дугом традиционалном употребом били чврсто међусобно синтаксички повезани. Сложенице су, дакле, обично некадашње синтагме, а ређе и некадашње целе реченице", сматра Стевановић, и истовремено наглашава да то није довољан разлог за настанак ових јединица, већ да такве конструкције подразумевају и друге процесе, као што је то промена значења, акцента и квантитета и промена у самом гласовном склопу њиховом (Стевановић 1964: 414). ${ }^{2}$

И. Клајн наводи да је главни критеријум за разликовање сраслица од сложеница синтаксички однос међу речима, те би стога термин сраслице требало задржати за оне сложенице које се од истих саставних делова, у истом облику и истом поретку могу јавити и као синтагме, дакле благдан, Бурђевдан, Београд, бабадевојка, даниноћ, такозвани, злурад, дангубити, акобогда и сл. Прелаз из синтагме у сложеницу означен је променом и уједначавањем значења, али и један и други могу бити само релативни, услед чега у правопису долази до недоумица (Клајн 2002: 28).

Други проблем је у вези са сраслицама и сложеницама без спојног вокала. Према Клајну, присуство или одсуство спојног вокала не би смело бити главно обележје за њихово разликовање јер нема ону важност која му је досад придавана, него је то, као што је већ речено, синтактички однос између речи. $^{3}$ Према С. Бабићу (2002: 366), чисте сложенице се обично деле на сложенице са спојником и сложенице без спојника, које се углавном не разли-

\footnotetext{
${ }^{2}$ И у кроатистичкој литератури Стевановићево поимање сраслица користи се готово у неизмењеном виду, на пример „поједине ријечи у синтагми често се рабе у истој комбинацији и устаљеним редослиједом. Ако такве ријечи уједно сачињавају једну акценатску цјелину, та се акценатска цјелина с временом може почети доживљавати као једна ријеч, са својим специфичним значењем. Тако схваћена акценатска цјелина почиње се заједно писати, а не више само заједно изговарати. На тај начин настају сраслице" (Вулић 2006: 115).

${ }^{3}$ На другом месту И. Клајн (2005: 211) сраслице одређује као сложенице у којима први и други део задржавају исти облик и исти међусобни однос какав су имали у синтагми од две речи, а једини знак спајања је јединствен акцент.
} 
кују од сраслица. Он објашњава да се речи сталнијег скупа каткада споје у сложеницу и тако настаје сраслица. Према томе, сраслице су само једна врста сложеница (Бабић 2002: 46-47). Надаље истиче да се сраслицама могу сматрати и неке сложенице без спојника, нпр. духанкеса, зимзелен, Иванград. Та Бабићева тврдња додатно збуњује јер показује да је упркос датом објашњењу тешко разликовати сложенице без спојника (или са спојником -ø-) и сраслице (Хорват/Рамадановић 2012: 143). Према А. Пејановић, у процесу срастања дешавају се следеће промене: фиксира се редослед компоненти полазне синтагме или реченице од које настаје нова лексема, новонастала јединица добија један (главни) акценат, што је такође доказ да се ради о лексеми, по правилу се мења и значење, а често и парадигма нове речи (Пејановић 2012: 691).

Јаснији критеријум за разликовање сложеница и сраслица износи Е. Барић, и то према начину њиховог постанка. Сраслице настају срастањем, то је, дакле, реч са сраслим деловима, а сложенице постају слагањем. „Дијелови сраслица могу се и одијељено написати, а дијелови сложеница не могу јер гласе нешто другачије него у двочланом појму с којим су у творбеној вези" (1980:23). Што се семантике тиче, Е. Барић наглашава да је њихово значење исто као и у основним речима, само што редослед основних речи може бити двојак: обичан и као у сраслици, тј. измењен, и тада је необичнији, обележенији. Она, такође, сматра да необичност и обележеност редоследа речи вероватно утиче и на појаву њиховог срастања (дан губити - дангубити, куће власница - кућевласниц̧а) (Барић 1980: 23).

Б. Тафра приступа сраслицама с лексиколошког становишта и објашњава их као једноречне јединице настале лексикализацијом. Поступак лексикализације ауторка сврстава у творбу речи у ширем смислу, јер нова лексичка јединица која тако настаје формално је и значењски целовита реч „без обзира на то што притом нису посриједи уобичајени творбени модели” (1998: 579).

У науци се поставља питање и о статусу процеса којим настају сраслице. С. Бабић тумачи срашћивање као један од подметода сложене творбе (2002: 46-47), док Е. Барић сматра да је овај творбени начин равноправан сложеној творби. М. Самарџија наводи да се каткад „догоди да два лексема срасту и тако настане твореница. (...) Тај се творбени начин назива срастање, а тако настале творенице називају се сраслицама" (2003:78). А. Пејановић говори о срашћивању као једном од начина неморфемске синтаксичке творбе (2012: 690).

Ми под сраслицама подразумевамо јединице које су настале без учешћа творбених форманата и то припајањем или повезивањем елемената који су изворно синтагматске или реченичне структуре у јединствену формалну, интонациону и значењску целину са одговарајућим графијским ликом и синтаксичком функцијом. 


\subsection{1. Типови сраслища у роману Сплеткарење са сопственом душом}

У овом роману сраслице се јављају у различитим структурним ликовима. Два су основна типа: срастање редуплицираних елемената у једну целину писаних scriptum continuит или повезивање речи или реченичних елемената цртицом.

\subsubsection{1. Сраслице писане scriptum continuum}

Сраслице овога типа садрже изразе или реченице која се у целокупној структури понављају више пута чинећи тако једну формалну и значењску целину.

а) Сраслице с поновљеним изразом

Док преживљава породичну и још више личну драму, у тренутку када сазнаје истину о свом мужу, главна јунакиња спас проналази у зазивању Свевишњег. Употребљене сраслице инкорпориране су у наративну форму, која добија димензију личног, веома субјективно обојеног исказа с наглашеном емотивношћу и дочараним стањем свести.

...непрекидно сам, као последњу одбрану, шапутала: божемојбожемојбожемој (С: 156)

Непрекидно дозивање Његове милости, кроз непрекидно божемојбожемојбожемој, спасило ме је те ноћи да не пређем танку линију која ме је делила од лудила (C: 156)

б) Сраслице с поновљеном реченицом

Најфреквентније употребљена сраслица у чијој је структури реченица с императивним значењем смири се јавља се у оквиру нарације с елементима унутрашњег монолога јунакиње романа док тешко повређена у критичном стању лежи у болници. Сраслицу смирисесмирисесмирисе употребљава као аутосугестивно средство које ће јој помоћи да из бунила и подсвести прекорачи у рационално и свесно. Ова је сраслица у функцији психолошке карактеризације лика, а посебно наглашен стилски ефекат изазван је честим понављањем.

... какве везе имају очи са муком и палачинкама, смирисесмирисесмирисе (С: 210)

Боже, учини да умине бол, смирисесмирисесмирисе, време ми је легло на груди, притисло ме као камена громада, треба је крунити ... да бих лакше поднела њен терет, смирисесмирисесмирисе (С: 211)

...растајем се са душом, а овамо гуске гачу и лепећу крилима, шта је ово, све саме бесмислице, смирисесмирисесмирисе, жива сахрањена... (С: 212)

За разлику од примера са сраслицом смирисесмирисесмирисе, која на синтаксичком плану углавном има функцију уметнуте реченице, сраслица, која се у нешто модификованом виду такође чешће употребљава у унутрашњем монологу јунакиње, дадаћетебедачува односно дадаћетебедабрани јавља се увек уз посесивну заменицу моја као главни део синтагматског споја у функцији апозиције и са истом употребом на плану садржаја и карактеризације лика. 
Боже, молим те да дође Катарина, моја дадаћетебедачува, не могу да је дозовем (C: 211) ...увек ме је штитила, моја дадаћетебедабрани, време скаче с гране на грану... (C: 211)

Унутрашње болно стање главног лика сликовито је дочарано посредством сраслице која је носилац предикације у оквиру реченице са онеобичајеним субјектом па, стога, цела реченична конструкција има наглашену стилску обојеност.

Ово су могла бити наша деца (бол-нож ријелиријеријелирије) (C: 205)

Са другачијом намером ауторка креира сраслице настале спајањем уобичајених идиоматских израза, као што су то пишелипишепанезнадастане или причамтипричу. Они су део јунакињиног размишљања или тумачења феномена везаних за поједине филозофске, егзистенцијалне теме и проблеме, дакле на идејном, а не само на емотивном плану као у претходним примерима.

Но, пустимо Хегела на миру да пишелипишепанезнадастане своја дела; није он макар ко. (С: 7)

Дочим човек опстаје. Не зато што он (човек) користи интелигенцију, па, као, рационализује, као, прилагођава се; не, све је то причамтипричу (С: 30)

\subsubsection{2. Сраслице с елементима повезаним цртицом}

Међу често употребљеним сраслицама чији су елементи повезани цртицом разликујемо више типова на основу њихових конституената.

a) Полусложенички спојеви састављени од идиоматизованих реченичних исказа због своје петрифициране форме задовољавају један од услова да постану сраслице. Значајнија је, међутим, њихова синтаксичка улога, која представља извор стилских ефеката.

\begin{tabular}{|l|l|}
\hline $\begin{array}{c}\text { Синтаксичка } \\
\text { функција } \\
\text { полусложеничног } \\
\text { споја }\end{array}$ & \multicolumn{1}{c|}{ Примери } \\
\hline \multirow{2}{*}{ део предиката } & $\begin{array}{l}\text { ‥шта он зна кад живи у нормалној земљи, овде је све другачије, } \\
\text { овде смтно озбиљно, увек бити-или-не-бити... (С: 106) } \\
\text {...нека те и зову миш-бели-срећу-дели, погледај каква си (С: 15) }\end{array}$ \\
\hline субјекатска & Још једно сад-или-никад се претворило у ништа. (182) \\
\hline \multirow{2}{*}{ адвербијална } & Три године тако, а сад, он је ту, главом-и-брадом (С: 47) \\
\cline { 2 - 3 } & $\begin{array}{l}\text { како је јадан и непримерен декор, траљаво склепан од очи- } \\
\text { гледно на-врат-на-нос обојадисаних кулиса... (С: 74) }\end{array}$ \\
\hline
\end{tabular}

б) Други модел представљају сраслице с елементима који припадају устаљеним изразима, заснованим на уобичајеним лексичким варијантама, чија је употреба ситуационо условљена. Такви изрази су, дакле, пригодног карактера. 
Прича за лаку-ноћ-и-мирно-спавај (C: 110)

За разлику од бајки које сам измишљала за Сару, за њено лаку-ноћ-и-лепо-сањај, постоји једна прича у којој је свака реч истинита. (С: 133)

Ауторка уноси лексичке варијације у устаљене спојеве и тако постиже стилске ефекте, као у примеру предавање-у-наставиима према уобичајеном роман у наставцима и сл. ${ }^{4}$

Овој групи се могу придружити наслови књига, Болест на смрт Серена Кјеркегора и Воља за моћ Фридриха Ничеа.

А ја сам тог самотничког лета тонула у најцрње очајање, у „болест-на-смрт” (С: 131)

Имао је само 42 године када се окончала болест-на-смрт (С: 136)

...причу мог живота, чија аљкава и упадљиво невешта изведена сценографија одаје утисак (Озирис) отелотворење воље-за-моћ, лишен искреног заноса према било чему... (C: 76)

в) Реализован је и модел срастања читавих реченица у полусложеничку конструкцију. Реченице срасле у целину карактеристичне су за разговорни језик и стога задовољавају један од критеријума срастања будући да се у истој форми и сличном поретку елемената често употребљавају.

Између њих и нас су стајала затворена врата собе; привидно, она су значила радите-шта-хоћете, док су, у ствари, била метафора немоћног очаја у који би они, наводно због нас, западали. (C: 21)

Превозна средства која су функционисала по принципу долазе-кад-стигну и возе-док-могу, постала су српска верзија античких тргова. (С: 33)

Не морају они ништа, мислим; за најмању ситницу сазивају породично веће, стрељају нас „како-сте-незахвалне”, „ита-вама-недостаје” погледима. (С: 56)

... неуклопљену мајку, чија је пословична војвођанска тежња ка тачности и реду, а пре свега према оном „,тако-треба-јер-тако-сав-нормалан-свет-ради” изгубила битку с њиховим ... обдарујућим ставом према свету... (С: 118)

...а и даље ме гледа испод ока као да радим не-знам-ни-ја-ита. (184)

Није му (Хераклиту) падало на памет да срозава своју мисао да би је народ-као-такав схватио. (С: 33)

- Марина, Марина... - каже једва чујно, без осветничког и прекорног ита-си-то-урадила призвука; (С: 193)

г) Полусложенички спојеви јављају се и као атрибутски део именичке синтагме:

...тај површни, здраворазумски, y-сумғу-не-доводећи поглед који се заснива на наивном прихватању непосредности, треба размакнути као завесу. (C: 20)

д) Посебно су стилски обележени полусложенички спојеви с одређеном синтаксичком функцијом чији лексички састав има упоришта како у разговорном језику тако и у поновљеним ситуацијама у садржају романа.

\footnotetext{
${ }^{4}$...већ сасвим ноншалантних и упућених у компликовани свет легендарних предаваға-у-наставцима професора Павловића. (С: 69)
} 


\begin{tabular}{|c|c|}
\hline $\begin{array}{c}\text { Синтаксичка } \\
\text { функција } \\
\text { полусложеничног } \\
\text { споја }\end{array}$ & Примери \\
\hline субјекатска & $\begin{array}{l}\text { Деловало је нестварно и далеко, неки-тамо-Василис-у-некој- } \\
\text {-тамо-Грчкој, можда једна од Марининих фантазија на које } \\
\text { се он одавно навикао. (С: 51) }\end{array}$ \\
\hline $\begin{array}{l}\text { атрибутска } \\
\text { функција }^{5}\end{array}$ & $\begin{array}{l}\text { одговор на његово треће (писмо) стизао би тек у мом петом } \\
\text { писму, јер је он прва два, као и ја своја четири, послао пре } \\
\text { одговора, као унапред-попуғавағе-празнине, као унапред- } \\
\text {-брисање-суза које још нису потекле... (С: } 59) \\
\text { Пошто је сваки покушај остваривања те сумануте потребе } \\
\text { и нестрпљивог „сада-одмах-и-заувек”, наравно, осуђен на } \\
\text { неуспех, остајем вечно носталгична. (С: 203) ...jа сам пред- } \\
\text { стављьла отелотворење мушког архетипа жене-светице-мај- } \\
\text { ке-девојчице. (С: } 103)\end{array}$ \\
\hline објекатска & $\begin{array}{l}\text { Василис и Озирис; несрећа се захуктавала, ја сам је поспе- } \\
\text { шивала; у једном сам имала све, у другом сам тражила још- } \\
\text {-мало-преко-свега; (C: } 81)\end{array}$ \\
\hline
\end{tabular}

ђ) У роману су веома фреквентни двочлани спојеви који се састоје од различитих лексичких елемената. Међу њима се посебно издвајају облици с негацијом, употребом негационе партикуле.

\begin{tabular}{|c|c|}
\hline $\begin{array}{l}\text { Структурни } \\
\text { тип }\end{array}$ & Примери \\
\hline \multirow{4}{*}{ не + именица } & $\begin{array}{l}\text { Свесна своје не-лепоте, коју ми фамилија није опраштала... } \\
\text { (С:24) }\end{array}$ \\
\hline & $\begin{array}{l}\text { Ужасава ме помисао метафизичке непробојности, свако не-пре- } \\
\text { сецағе, не-спајање, призор испружених руку које не могу да се } \\
\text { додирну. (C: } 61)\end{array}$ \\
\hline & $\begin{array}{l}\text { Истина је оно што из мрака и скривености, из неке тајне, бива } \\
\text { дозвана у светло, у не-скривеност. (С: } 85)\end{array}$ \\
\hline & $\begin{array}{l}\text {...кожних капута који лупају у не-доба и одводе човека у непо- } \\
\text { знато. (С: } 166) \\
\text { побеђивали смо не-страхом, смехом и пиштаљкама (C: } 182)\end{array}$ \\
\hline
\end{tabular}

\footnotetext{
${ }^{5}$ Покушај остваривања нестрпљивог сада-одмах-и-заувек, исто као покушај остваривања сумануте потребе, а све заједно попуњава позицију субјекта.
} 


\begin{tabular}{|l|l|}
\hline \multirow{5}{*}{ не + придев } & $\begin{array}{l}\text { Прича за не-лаку ноћ (С: 133) } \\
\text { Пошто је ово прича за не-лаку ноћ (С:135) } \\
\text {...јер их је тако спаковане (варварске изливе емотивности) и не- } \\
\text {-живе могао контролисати... (С: 142) }\end{array}$ \\
\cline { 2 - 2 } & $\begin{array}{l}\text { Огледајући се не-скривена у његовим (Василисовим) очима, } \\
\text { душа није била себи странац и непријатељ, већ неко с ким се } \\
\text { могу помирити и кога могу прихватити. (С: 86) }\end{array}$ \\
\hline \multirow{2}{*}{ не + прилог } & $\begin{array}{l}\text { „Истину” су означили термином alithia, што дословно значи не- } \\
\text {-скривено. }\end{array}$ \\
\hline
\end{tabular}

Поједине негиране форме имају одговарајући лексички еквивалент, као не-лепа према ружна, не-живе према мртве, не-страхом према неустрашивошћу, не-лаку према тешку ноћ. Такви спојеви имају еуфемистички ефекат. Међутим, поступак одвајања негираног дела цртицом у случајевима где правопис налаже спојено писање има функцију интензификатора (не-пресецањье, не-спајање, не-скривена, не-доба).

Овом структурном типу припадају и бинарне јединице с предлогом без, у којима он доследно реализује значење 'одсуство, непостојање одређеног својства'. Посебним издвајањем предлога у лексикализованим облицима такође се постиже ефекат интензификације (без-сузно према бесузно), а још више у творевинама писца, као у без-борбено према неборбено и потпуно условљено садржајем дела без-василисовог. Креирани облици део су синтагми, и у споју с одређеном именицом њихов стилски ефекат је израженији (без-сузно лето, без-борбено послушање), посебно у споју нема без-василисовог између, где се предлог између употребљава у именичкој функцији.

\begin{tabular}{|c|c|}
\hline $\begin{array}{c}\text { Структурни } \\
\text { тип }\end{array}$ & Примери \\
\hline \multirow{3}{*}{ без + придев } & Онда је прошло и то без-сузно лето које сам одболовала. (С: 137) \\
\hline & $\begin{array}{l}\text { Није то било ... пасивно и без-борбено послушање, већ верујуће } \\
\text { и топло „ево ме, Господе” (С: 171) }\end{array}$ \\
\hline & $\begin{array}{l}\text { Све што се десило између не постоји; нема без-василисовог из- } \\
\text { међу, у коме је чулност ... била ... недовољна замена за љубав; } \\
\text { (С: 201) }\end{array}$ \\
\hline
\end{tabular}

е) Посебан двочлани структурни тип представља полусложенички спој двеју пунозначних речи. Високо фреквентни су спојеви с лекемом бол, који се употребљавају као номинационо средство. Лапидарно и метафорично именовање унутрашњих болова које писац градира и детерминише именицом талас, коцка, нож или игла чини да апстрактум постане конкретан, опредмећен појам. ${ }^{6}$

\footnotetext{
${ }^{6}$ Структуре овога типа имају подршку у лексичком систему српског језика и оне су могле настати по аналогији са именичким полусложеницама рак-рана, сахат-кула и сл. Са стилистичког
} 


\begin{tabular}{|c|c|}
\hline \multirow[b]{2}{*}{ бол-талас } & Бол-талас има временску одредницу, тј. дужину трајања. (С: 160) \\
\hline & $\begin{array}{l}\text {...понекад се наизглед огроман бол-талас, у судару са добро при- } \\
\text { премљеном душом, претвара у безопасно поигравање... (C: } 160)\end{array}$ \\
\hline \multirow{6}{*}{ бол-коцка } & Бол-коцүка се врло дословно обликује у простору. (С: 160) \\
\hline & Бол-коика се лакше подноси (С: 161) \\
\hline & $\begin{array}{l}\text {..бол-кочка може да прерасте објекат на који належе и да га потпуно } \\
\text { поклопи (С: 161) }\end{array}$ \\
\hline & Бол-коияка је обично веома тежак... (C: 161) \\
\hline & $\begin{array}{l}\text { Лично се против бола-коике борим тако што сву снагу улажем у то } \\
\text { да му раст зауставим у подношљивим сразмерама. (C: 161) }\end{array}$ \\
\hline & Бол-коика је трајно смештен у прошлост (С: 161) \\
\hline \multirow{2}{*}{ бол-нож } & $\begin{array}{l}\text { „Бол-ножс" се физички уобличава у огромну, претећу иглу или ош- } \\
\text { трицу... (С: 161) }\end{array}$ \\
\hline & $\begin{array}{l}\text {...Бол-нож, међутим, једном ногом пребива у прошлости, а другом } \\
\text { је ногом чврсто у садашњости. (С: } 162)\end{array}$ \\
\hline бол-игла & $\begin{array}{l}\text { Бол-игла или бол-оштро-сечиво-ножа представља неразрешив про- } \\
\text { блем за мене. (С: } 161)\end{array}$ \\
\hline
\end{tabular}

ж) Фреквентни су и веома сликовити спојеви с личним именом Василис, које има функцију квалификатора и даје посебно значење именици с којом је у вези: реченица, звезда, планета.

Дуго ми је требало да се навикнем на те ... Василис-реченице; падале су, ненајављено, са Василис-звезде... (С: 26)

У свему учествује, а није ту. Отишао на Василис-планету. (С: 81)

3) Креирани и су и полусложенички спојеви с негираним и афирмативним обликом који чине једну садржајно структурну целину.

Када сам се ... прикључила ... крајње некохерентној и еластичној неорганизовано-организованој организацији ... (C: 103)

... да телесношћу отопе телесне опне и створе међутелесну, телесно-нетелесну ауру, астрални простор ... у који су ступале наше огољене душе... (С: 204)

аспекта, оне представљају хифенску метафору, која настаје „тако што се апозитивна метафора састављена само од двију именица уједини у полусложеницу, или је на путу да постане полусложеница, и то тако што се наведене именице повезују цртицом” (Ковачевић 2000: 26). 


\section{4. Закључак.}

Лексички и деривациони систем српског језика не подржава јединице настале процесом срастања. Први разлог томе јесте неекономичност таквог језичког израза, као и веома често замагљене референцијалне, па и номинационе функције, а посебно оне које су на нивоу језичког експеримента јер не задовољавају један од основних услова срашћивања - учесталост употребе одређеног синтагматског или реченичног споја. Наиме, њихова референцијалност ишчитава се на основу реченичног или ширег контекста и на основу синтаксичке функције.

У књижевном делу мотивација за употребу сраслица првенствено је стилске природе и у њему оне функционишу као стилогени доприносећи при томе психолошкој карактеризацији лика. У том смислу ауторка користи неуобичајене спојеве произишле из самог садржаја дела. Другачије је мотивисана употреба јединица заснованих на срашћивању уобичајених синтагматских или синтаксичких конструкција јер су оне у функцији идејне карактеризације књижевног лика. На синтаксичком плану сраслице и полусложенички спојеви могу да обављају све функције, те се стога могу сматрати конструкцијама које могу да подлегну процесу лексикализације.

Основни поступак у грађењу сраслица заснива се на редупликацији, која је уједно и стилски поступак и у функцији интензификатора што се може сматрати креативним чином писца. Лексички спојеви са цртицом користе се у потпуно другачијем контексту. Они не служе као средство карактеризације лика, већ су у функцији дочаравања атмосфере или појединих психолошких или социјалних феномена или су употребљени као дескриптори.

\section{ЛИТЕРАТУРА}

Бабић 2002: Stjepan Babić, Tvorba riječi u hrvatskome književnome jeziku. Treće, poboljšano izdanje, Zagreb: Nakladni zavod Globus-HAZU.

Барић 1980: Eugenija Barić, Imeničke složenice neprefiksalne i nesufiksalne tvorbe, Zagreb: Hrvatsko filološko društvo.

Барић 1997: Eugenija Barić, Hrvatska gramatika, II promijenjeno izdanje, Zagreb: Školska knjiga.

Вулић 2006: Sanja Vulić, Imeničke sraslice u gradišćanskohrvatskim govorima, Čakavska rič, XXXIV/1-2, Split, 115-119.

Гордић Петковић 2011: Vladislava Gordić Petković, Ženski glasovi u savremenoj srpskoj književnosti, Slavistična revija, 59/3, 307-315. http://www.srl. si/sql_pdf/SRL_2011_3_04.pdf

Клајн 2002: Иван Клајн, Творба речи у савременом српском језику, Први део - слагање и префиксачија, Београд: Завод за уџбенике и наставна средства. 
Клајн 2005: Ivan Klajn, Gramatika srpskoga jezika, Beograd: Zavod za udžbenike i nastavna sredstva.

Ковачевић 2000: Милош Ковачевић, Стилистика и граматика стилских фигура, Крагујевац: Кантакузин.

Kox 2012: Magdalena Koh, Kada sazremo kao kultura: stvaralaštvo srpskih spisateljica na početku XX veka (kanon - žanr - rod)), Београд: Službeni glasnik. https://polja.rs/wp-content/uploads/2015/12/479-28.pdf

Самарџија 2003: Marko Samardžija, Hrvatski jezik 4. Udžbenik za 4. razred gimnazije, Zagreb: Školska knjiga.

Свирчев 2012: Žarka Svirčev, Knjiženstvo izvan sopstvene sobe (Magdalena Koh: ...kada sazremo kao kultura: stvaralaštvo srpskih spisateljica na početku XX veka (kanon - žanr - rod)), Beograd: Službeni glasnik.

Стевановић 1964: Михаило Стевановић, Савремени српскохрватски језик, I, Београд: Научно дело.

Taфpa 1998: Branka Tafra, Leksikalizacija kao leksikološki i leksikografski problem, Jezična norma $i$ varijeteti, Zagreb-Rijeka: HDPL, 575-581.

Хорват/Рамадановић 2012: Marijana Horvat, Ermina Ramadanović, O složenicama i sraslicama (na primjerima iz Voltićeva Ričoslovnika), Filologija, 58, Zagreb: Institut za hrvatski jezik i jezikoslovlje, 133-161.

https://www.researchgate.net/publication/275465067_O_slozenicama_i_sraslicama_na_primjerima_iz_Volticeva_Ricoslovnika_About_compounds and_blends_with_examples_from_Voltic's_Ricoslovnik [accessed Aug 20, 2017].

file://C:/Documents_and_Settings/Administrator/My_Documents/Downloads/ Sanja_Vulic_Imenicke_sraslice20(1).pdf

Gordana R. Štasni

\section{COMPLEX WORDS AND SEMI-COMPOUND CONSTRICTIONS IN THE NOVEL SPLETKARENJE SA SOPSTVENOM DUŠOM BY MARIJA JOVANOVIĆ}

\section{Summary}

The paper deals with complex words and semi-compound constructions in the novel Spletkarenje sa sopstvenom dušom by Marija Jovanović. The tipology of these constructions are based on the criteria of composed of their constituents according to their structure and frequency in the context of the novel. The resultates of analysis showed that their productvity and usage are on the level of language experimente. So, these constructions are conditioned by the context of novel. This data is an important indicator for their semantic-derivative potential and for their unproductivity in Serbian.

Keywords: complex words, semi-compound constructions, Serbian. 